Marcin Feltynowski

ROZDZIA $九$ III

\title{
Infrastruktura ICT jako element inwestycji w kapitał ludzki. Przykład szkół ponadgimnazjalnych województwa łódzkiego
}

\section{Wstęp}

Społeczeństwo informacyjne w XXI wieku jest podstawą rozwoju sfery gospodarczej, społecznej, kulturowej, środowiskowej i przestrzennej. Wykorzystywanie nowych technologii w życiu codziennym, staje się nieodzownym elementem funkcjonowania i budowania konkurencyjności jednostki ludzkiej. Nauka i wykorzystywanie komputerów w procesie kształcenia pozwala na rozwój kapitału ludzkiego i jego akumulację w regionie. Konieczność budowania społeczeństwa informacyjnego wynika chociażby z faktu, że w ostatnim trzydziestoleciu wytworzono więcej informacji niż $\mathrm{w}$ ciągu pięciu tysiącleci ${ }^{1}$. Ważnym elementem rozwoju, jest często podkreślana, rola edukacji z wykorzystaniem komputera $\mathrm{w}$ zajęciach prowadzonych w szkołach. Możliwości w tym zakresie określane są przez czynniki twarde i miękkie. Do czynników twardych zaliczyć można dostępność komputerów z dostępem do sieci Internet. Kształcenie w zakresie ICT wynika również z potrzeby wyrównywania poziomu umiejętności $\mathrm{w}$ ujęciu regionalnym, jak również w odniesieniu do lokalizacji szkoły na obszarach wiejskich i w miastach.

Kształcenie przy użyciu komputerów powinno prowadzić do aktywizacji uczniów, którzy w zajęciach powinni wykazywać się kreatywnością i chęcią współpracy. Należy pamiętać, że rola nauczyciela jest równie istotna, jak postawa uczniów. Podstawą pracy nauczyciela staje się dostępność nowych technologii i komputerów w szkole. Kolejnym etapem pracy z uczniem jest umiejętne wykorzystanie tych narzędzi. Zadaniem nauczycieli umiejętne przechodzenie od

* Adiunkt, Katedra Gospodarki Regionalnej i Środowiska, Wydział Ekonomiczno-Socjologiczny, Uniwersytet Łódzki. E-mail: marcinf@uni.lodz.pl

1 W.D. Haddah, A. Draxler, The Dynamics of Technologies for Education, 2003, http://www.ictinedtoolkit.org/usere/library/tech_for_ed_chapters/01.pdf. 
pasywnego wykorzystania komputera, np. w formie prezentacji slajdów do interaktywnego uczestnictwa $\mathrm{w}$ zajęciach, gdzie nauczyciel jest partnerem dla ucznia w rozwiązywaniu złożonych problemów.

Rysunek 1. Zmiana roli nauczyciela i ucznia w przypadku zastosowania komputera

\section{Rola nauczyciela}

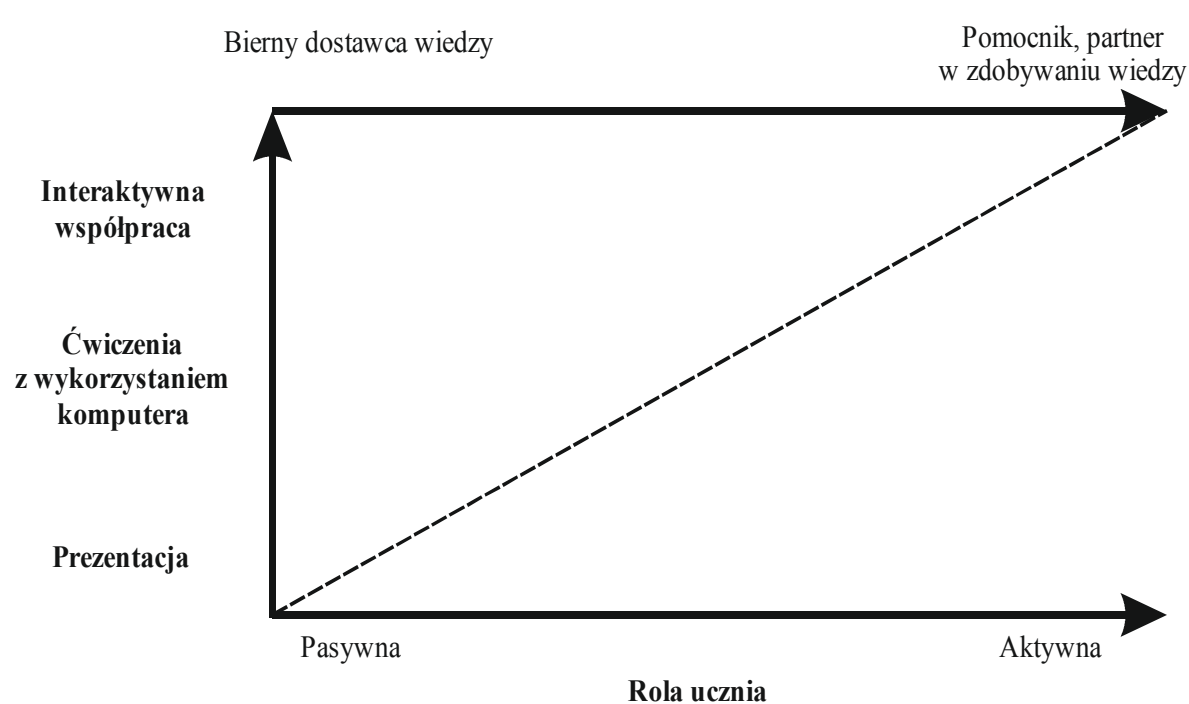

Źródło: Opracowanie własne na podstawie W.D. Haddah, A. Draxler, The Dynamics of Technologies for Education, 2003, s. 13, http://www.ictinedtoolkit.org/usere/library/tech_for_ed_chapters/01.pdf.

W przypadku uczniów, ważnym elementem staje się aktywne podejście do kształcenia $\mathrm{z}$ wykorzystaniem komputera oraz chęć rozwijania swoich umiejętności w tym zakresie, zarówno podczas zajęć określonych przez treści kształcenia, jak również rozwijanie swoich umiejętności poza szkołą. Miejscem, w którym rozwijać mogą się indywidualne umiejętności jest szkoła oraz dom ucznia, gdzie może on poznawać różnego rodzaju narzędzia i oprogramowanie specjalistyczne, co pozwala na podnoszenie kompetencji oraz akumulację kapitału ludzkiego. 
Tabela 1. Od paradygmatu szkoły tradycyjnej do paradygmatu szkoły wykorzystującej technologie informacyjne $w$ kształceniu

\begin{tabular}{|l|l|}
\hline \multicolumn{1}{|c|}{ Model tradycyjny } & Model oparty o technologie informacyjne \\
\hline Budowa szkół & $\begin{array}{l}\text { Budowa infrastruktury wiedzy - laboratoriów, } \\
\text { sal komputerowych, sieci Internet }\end{array}$ \\
\hline Nauczanie w klasach & $\begin{array}{l}\text { Nauczanie zindywidualizowane - zajęcia poza- } \\
\text { lekcyjne, praca w mniejszych grupach }\end{array}$ \\
\hline Nauczyciel, jako bierny dostawca wiedzy & $\begin{array}{l}\text { Nauczyciel, jako opiekun i koordynator procesu } \\
\text { kształcenia }\end{array}$ \\
\hline $\begin{array}{l}\text { Podręczniki, jako podstawowe narzędzie } \\
\text { nauczania }\end{array}$ & $\begin{array}{l}\text { Materiały multimedialne - drukowane, elektro- } \\
\text { niczne }\end{array}$ \\
\hline
\end{tabular}

Źródło: Opracowanie własne na podstawie W.D. Haddah, A. Draxler, The Dynamics of Technologies for Education, 2003, s. 8, http://www.ictinedtoolkit.org/usere/library/tech_for_ed_chapters/01.pdf.

Tego rodzaju podejście do sfery kształcenia prezentuje również konieczność budowania nowego paradygmatu rozwoju młodego człowieka w szkole. Nowe podejście prezentowane w literaturze ${ }^{2}$, wskazuje na konieczność wykorzystywania technik informacyjnych przez uczniów i nauczycieli. Podstawą staje się budowanie zaplecza infrastrukturalnego w szkołach, w postaci dobrze wyposażonych sal komputerowych z możliwością dostępu do sieci Internet. Ważnym aspektem rozwoju stają się również laboratoria, pozwalające na pogłębianie wiedzy przy pomocy eksperymentów i doświadczeń prowadzonych przez uczniów. Ważnym elementem wskazywanym w literaturze przedmiotu staje się również ewolucja sposobu nauczania, oparta na pracy indywidualnej z uczniami. W przypadku polskich szkół, możliwości w tym zakresie należy upatrywać w zmniejszaniu liczebności oddziałów szkolnych oraz w prowadzeniu zajęć pozalekcyjnych, podczas których wychowawcy pracować mogą z mniejszą liczbą uczniów. Podkreśla się również rolę nauczyciela, który staje się opiekunem i koordynatorem działań podejmowanych przez uczniów. Przestaje być on biernym dostawcą ,suchej” wiedzy. W założeniach nowego paradygmatu nauczania podkreśla się również wykorzystanie nowoczesnych technik w przekazywaniu wiedzy, przez co zajęcia mogą stawać się atrakcyjniejsze. Przekazywanie wiedzy musi odbywać się przy użyciu metod aktywizujących (np. dyskusja, „burza mózgów", analiza przypadków, praca w grupach).

2 W.D. Haddah, A. Draxler, The Dynamics of Technologies for Education, 2003, http://www.ictinedtoolkit.org/usere/library/tech_for_ed_chapters/01.pdf; I. Kołodziejczyk, ICT for education - the way ahead, but how?, Contemporary PNG Studies, Nov2009, Vol. 11, s. 26-38; J. Sanchez, A. Salinas, J. Harris, Education with ICT in South Korea and Chile, International Journal of Educational Development 31 (2011); J.C. Lundt, A New Paradigm for Education, Futurist, Nov/Dec2004, Vol. 38 Issue 6; D. Shantz, G. Rideout, Education versus schooling: seeking new paradigms for a new century, Education, Fall2003, Vol. 124 Issue 1. 
Wykorzystanie nowego podejścia w sferze edukacji uzależnione jest od wielu czynników, które zaliczyć można do trzech grup:

- czynniki związane ze szkołą;

- czynniki związane z systemem edukacji;

- czynniki społeczne.

Rysunek 2. Czynniki wpływające na wykorzystanie ICT w szkołach

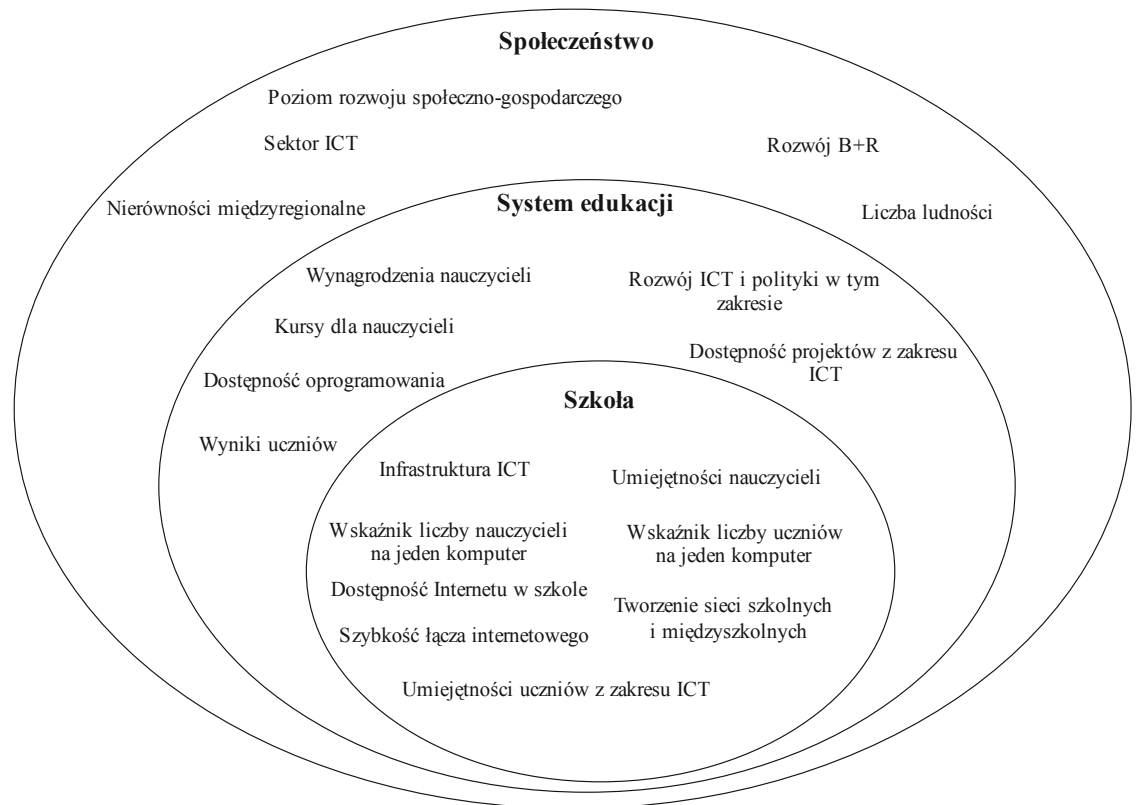

Źródło: Opracowanie własne na podstawie J. Sanchez, A. Salinas, J. Harris, Education with ICT in South Korea and Chile, International Journal of Educational Development 31 (2011), s. 129.

Czynniki zostały podzielone $\mathrm{w}$ zależności od zakresu ich oddziaływania. Najważniejszym z nich jest rozbudowa infrastruktury komputerowej w szkołach. Wynika to $\mathrm{z}$ faktu, że polskie społeczeństwo zaakceptowało konieczność nauczania z wykorzystaniem komputerów do szkół, co przełożyło się na system edukacji. Obecnie wszystkie szkoły starają się o rozwój zaplecza infrastrukturalnego, w celu zachęcenia uczniów do rozwijania umiejętności z zakresu wykorzystania komputerów.

Rozwój edukacji z wykorzystaniem ICT wiąże się z dostępnością komputerów w szkołach oraz podejściem uczniów i nauczycieli do ich powszechnego wykorzystania. Fakt oceny tych elementów, możliwy jest poprzez pryzmat do- 
stępności komputerów z dostępem do sieci Internet w szkołach ponadgimnazjalnych. W przypadku realizowanego badania analizie zostaną poddane: zasadnicze szkoły zawodowe, technika, licea profilowane i licea ogólnokształcące. Zestawienie tych danych $\mathrm{z}$ informacjami na temat samooceny uczniów tych placówek dotyczących kompetencji w zakresie wykorzystania komputerów i sieci Internet, pozwoli na ocenę stopnia zbieżności, pomiędzy dostępnością komputera w szkole, a kwalifikacjami, jakie posiadają uczniowie, którzy w niedługim czasie zostaną studentami, bądź wejdą na rynek pracy, jako kadry z wykształceniem technicznym i zawodowym.

Badanie obejmuje swoim zasięgiem województwo łódzkie. Analiza dostępności komputerów z podłączeniem do sieci Internetu opierać się będzie o dane zgromadzone w Banku Danych Lokalnych Głównego Urzędu Statystycznego. Ocena kompetencji posiadanych przez uczniów oparta będzie o dane zebrane podczas badań ankietowych Bilans Kapitału Ludzkiego 2010 wykonanych dla Polskiej Agencji Rozwoju Przedsiębiorczości (PARP) ${ }^{3}$. Wszystkie bazy danych dotyczące uczniów, są informacjami powszechnie dostępnymi i udostępnionymi do celów analitycznych.

Najważniejszym celem badania jest porównanie kompetencji, w zakresie posługiwania się komputerem i Internetem przez uczniów ostatnich klas szkół ponadgimnazjalnych. Badanie składać się będzie z analizy pytania głównego oraz poszczególnych elementów, na które pytanie to zostało zdekomponowane w ankietach, przeprowadzonych dla PARP. Poziom umiejętności we wszystkich pytaniach oceniany jest $\mathrm{w}$ skali od 1 do 5 , gdzie 1 oznacza bardzo niski stopień umiejętności, a 5 stopień bardzo wysoki. Weryfikacja poziomu umiejętności polegała na samoocenie stopnia kompetencji w zakresie znajomości pakietu Office, znajomości specjalistycznych programów oraz umiejętności pisania programów, bądź stron internetowych oraz wykorzystaniu Internetu, jako źródła informacji i komunikacji.

Jako cel badania, założone zostało zweryfikowanie dostępności komputerów $\mathrm{z}$ siecią Internet w szkołach ponadgimnazjalnych regionu. Sprawdzenie tego komponentu polega na zestawieniu różnic w liczbie uczniów, przypadających na jeden komputer oraz zidentyfikowaniu odsetka szkół, w których młodzież ma możliwość skorzystania z komputerów z dostępem do Internetu.

Ocena dwóch pierwszych celów pozwolić ma na analizę wzajemnych powiązań, pomiędzy sferą kompetencji kapitału ludzkiego w regionie z dostępnością komputerów. Uwzględnione zostaną w tym przypadku różnice pomiędzy

\footnotetext{
${ }^{3}$ Badanie Bilans Kapitału Ludzkiego 2010 jest częścią projektu realizowanego przez PARP i Uniwersytet Jagielloński pt. „Bilans Kapitału Ludzkiego”, który obejmować będzie badania rynku pracy. Założenia projektu wskazują, że zostanie przeprowadzonych 5 edycji badania, efektem czego ma być odpowiedź na kluczowe pytania z zakresu kapitału ludzkiego. Więcej informacji na stronie: http://bkl.parp.gov.pl/projekt.
} 
rodzajami szkół objętych analizą. Realizacja prezentowanych celów pozwolić ma na weryfikację hipotezy badawczej, czy dostępność komputerów w poszczególnych typach szkół ponadgimnazjalnych nie jest determinantą, generującą umiejętności wykorzystywania komputerów i Internetu wśród uczniów, min. w sferze komunikacji, wykorzystania pakietu biurowego Office oraz znajomości specjalistycznych programów.

Realizacja celów badawczych pozwoli na ocenę stopnia skomputeryzowania szkół w województwie łódzkim oraz porównanie tych informacji z kompetencjami wskazywanymi w badaniach ankietowych. Pozwoli to również na wyciągnięcie wniosków, czy dany typ szkoły ma wpływ na kompetencje uczniów w zakresie informatycznym. Analiza danych pozwoli również na ocenę podnoszenia swoich kompetencji przez uczniów szkół ponadgimnazjalnych, w zakresie znajomości oprogramowania, które wykracza poza ramy podstaw kształcenia.

Zestawienie danych dotyczących dostępności komputerów w szkołach ponadgimnazjalnych oraz poziomu umiejętności uczniów tych szkół, będzie możliwe dzięki zastosowaniu rangowania poszczególnych wskaźników i oceny lokaty poszczególnych typów szkół w rankingu. Weryfikacja dwóch rankingów pozwoli na skonstatowanie wniosków o prawdziwości lub nie, hipotezy badawczej.

\section{Komputeryzacja szkół ponadgimnazjalnych w wojewódz- twie łódzkim}

Jedną z miar, pozwalających na ocenę dostępności komputerów podłączonych do Internetu jest odsetek szkół, w których uczniowie mogą skorzystać $\mathrm{z}$ tego rodzaju infrastruktury. W województwie łódzkim odsetek ten jest wyższy od wskaźnika notowanego średnio w Polsce. Analiza wyszczególnienia, ze względu na obszar miejski i wiejski ukazuje, że szkoły ponadgimnazjalne zlokalizowane w miastach mają lepsze wyposażenie w infrastrukturę komputerową w stosunku do średniej krajowej. W przypadku obszarów wiejskich odsetek ten jest niższy niż średnia krajowa. Różnica między skomputeryzowaniem szkół na obszarach miejskich i wiejskich w województwie łódzkim wynosi 12 p.p., w przypadku Polski różnica ta nie przekracza 4 p.p. w 2010 roku.

Uwzględniając rodzaj szkoły ponadgimnazjalnej w województwie łódzkim, największą dostępnością komputerów charakteryzują się licea ogólnokształcące. Aż 83\% tych jednostek może zaproponować swoim uczniom skorzystanie z komputerów z dostępem do Internetu. Niewiele niższy wskaźnik notuje się w technikach, gdzie odsetek szkół wyposażonych w komputery wynosi $80,6 \%$. Znacznie słabiej w przypadku tej miary prezentują się licea profilowane i zasadnicze szkoły zawodowe, gdzie odsetek szkół zapewniających dostęp do Internetu dla uczniów wynosi odpowiednio: $54,5 \%$ i $29,4 \%$. 
Tabela 2. Odsetek szkół posiadających w wyposażeniu komputery z dostępem do Internetu

\begin{tabular}{|c|c|c|c|}
\hline Typ szkoły & Wyszczególnienie & Polska & Łódzkie \\
\hline \multirow[t]{3}{*}{ Zasadnicze szkoły zawodowe } & ogółem & 31,8 & 29,4 \\
\hline & miasto & 33,5 & 32,4 \\
\hline & wieś & 21,1 & 9,1 \\
\hline \multirow[t]{3}{*}{ Technika } & ogółem & 72,1 & 80,6 \\
\hline & miasto & 71,1 & 78,6 \\
\hline & wieś & 77,9 & 88,5 \\
\hline \multirow[t]{3}{*}{ Licea profilowane } & ogółem & 42,2 & 54,5 \\
\hline & miasto & 41,1 & 54,5 \\
\hline & wieś & 68,8 & 0 \\
\hline \multirow[t]{3}{*}{ Licea ogólnokształcące } & ogółem & 78,6 & 83 \\
\hline & miasto & 79,7 & 87,3 \\
\hline & wieś & 66,5 & 40.0 \\
\hline \multirow[t]{3}{*}{ Szkoły ponadgimnazjalne ogółem } & ogółem & 63,1 & 68,3 \\
\hline & miasto & 63,5 & 69,7 \\
\hline & wieś & 59,8 & 57,7 \\
\hline
\end{tabular}

Źródło: Opracowanie własne na podstawie danych Banku Danych Lokalnych Głównego Urzędu Statystycznego.

W prowadzonej analizie widać, że jedynie w przypadku techników omawiany wskaźnik notował wyższe wartości w szkołach ulokowanych na obszarach wiejskich. W liceach ogólnokształcących różnica pomiędzy miastem a wsią wynosiła ponad 47 p. p. W przypadku zasadniczych szkół zawodowych różnica ta wyniosła ponad 23 p. p. Zestawienie danych dla liceów profilowanych wykazało, że wartość dla jednostek zlokalizowanych na obszarach wiejskich wynosi 0 . Wynikać to może z niewielkiej liczby tych jednostek na obszarach wiejskich, gdyż zgodnie z danymi Systemu Informacji Oświatowej (SIO) na obszarach wiejskich znajduje się 8 liceów profilowanych.

Miarą pozwalającą na ocenę dostępności komputerów podłączonych do sieci Internet dla uczniów jest liczba osób przypadająca na jeden komputer. Zgodnie z przypuszczeniami, wynikającymi z wyższego od średniej krajowej odsetka szkół z tego rodzaju sprzętem komputerowym dla wychowanków, okazuje się, że w województwie łódzkim notowane są także niższe wskaźniki liczby uczniów przypadających na jeden komputer. Różnice te są nieznaczne i kształtują się na poziomie od 0,2 do 0,4 osoby na komputer. Najmniejszą różnicę na korzyść regionu łódzkiego wykazują szkoły na obszarach miejskich 0,2 , największą zaś wykazują szkoły na obszarach wiejskich $-0,4$, również na korzyść obszarów wiejskich województwa łódzkiego. 
Infrastruktura ICT jako element inwestycji w kapitał ludzki...

Tabela 3. Liczba uczniów przypadająca na jeden komputer z dostępem do Internetu

\begin{tabular}{|l|l|c|c|}
\hline \multicolumn{1}{|c|}{ Typ szkoły } & Wyszczególnienie & Polska & Łódzkie \\
\hline \multirow{4}{*}{ Zasadnicze szkoły zawodowe } & ogółem & 16,7 & 16,8 \\
\cline { 2 - 4 } & miasto & 16,6 & 16,3 \\
\cline { 2 - 4 } & wieś & 17,5 & 32,1 \\
\hline \multirow{4}{*}{ Technika } & ogółem & 6,6 & 6,3 \\
\cline { 2 - 4 } & miasto & 7,0 & 6,9 \\
\cline { 2 - 4 } & wieś & 4,6 & 4,1 \\
\hline \multirow{4}{*}{ Licea profilowane } & ogółem & 7,4 & 6,1 \\
\cline { 2 - 4 } & miasto & 7,7 & 6,1 \\
\cline { 2 - 4 } & wieś & 3,0 & 0,0 \\
\hline \multirow{4}{*}{ Licea ogólnokształcące } & ogółem & 9,8 & 9,7 \\
\cline { 2 - 4 } & miasto & 10,0 & 9,7 \\
\cline { 2 - 4 } & wieś & 6,2 & 8,3 \\
\hline \multirow{4}{*}{ Szkoły ponadgimnazjalne ogółem } & ogółem & 9,7 & 8,4 \\
\cline { 2 - 4 } & miasto & 5,5 & 8,8 \\
\cline { 2 - 4 } & wieś & & 5,1 \\
\hline
\end{tabular}

Źródło: Opracowanie własne na podstawie danych Banku Danych Lokalnych Głównego Urzędu Statystycznego.

Uwzględniając poszczególne typy szkół ponadgimnazjalnych poddanych analizie, należy stwierdzić, że najniższe wartości ${ }^{4}$ wskaźnika zidentyfikowano paradoksalnie $\mathrm{w}$ liceach profilowanych. Wynika z tego, że liczba komputerów w tych szkołach pozwala na zaspokajanie potrzeb edukacyjnych uczniów. W przypadku tego rodzaju szkół na obszarach wiejskich uczniowie nie mogli korzystać z komputerów, co zostało również podkreślone we wskazaniu odsetka szkół, posiadających na wyposażeniu komputery z dostępem do sieci Internet. Jeżeli chodzi o technika, średni wskaźnik wyniósł 6,3 osoby na komputer, co było wynikiem lepszym niż wartość średnia dla kraju. Dużo wyższą dostępnością komputerów wykazać się mogły szkoły zlokalizowane na obszarach wiejskich, gdzie omawiany wskaźnik wynosił 4,1 osoby, w przypadku, gdy w miastach kształtował się on na poziomie 6,9.

Licea ogólnokształcące charakteryzowały się dostępnością komputerów dla uczniów na poziomie 9,7 osób na komputer. Był to wynik lepszy od średniej krajowej o zaledwie 0,1. Podobnie jak w przypadku techników lepszą dostępność komputerów wykazywały szkoły zlokalizowane na obszarach wiejskich. Różnica polegała jednak na tym, że na obszarach miast omawiany wskaźnik był

\footnotetext{
${ }^{4}$ Wskaźnik liczby uczniów przypadających na jeden komputer z dostępem do Internetu jest destymulantą.
} 
niższy od średniej krajowej o 0,3, a w przypadku obszarów wiejskich wielkość ta była o 2,1 wyższa niż średnia krajowa. Pozwala to na stwierdzenie, że obszary wiejskie w województwie łódzkim charakteryzują się niską dostępnością komputerów w liceach ogólnokształcących.

Najsłabiej w zestawieniu poszczególnych typów szkół ponadgimnazjalnych wypadają zasadnicze szkoły zawodowe. W ich przypadku stwierdzono, że liczba uczniów przypadających na jeden komputer wynosi 16,8, co jest wynikiem nieznacznie gorszym od średniej krajowej. Sytuacja dostępności na obszarach miejskich pokazuje, że w województwie łódzkim omawiany wskaźnik osiaga wartość 16,3 i jest lepszy od wskaźnika notowanego w Polsce o 0,3. Sytuacja zupełnie inaczej wygląda na obszarach wiejskich, gdzie widać ogromną przepaść pomiędzy wskaźnikami dostępności komputerów w regionie łódzkim i w Polsce. Województwo łódzkie charakteryzuje się bowiem wskaźnikiem na poziomie 32,1. Jest to wartość blisko dwukrotnie wyższa od średniej krajowej, co stawia w złym świetle zasadnicze szkoły zawodowe, zlokalizowane na obszarach wiejskich województwa łódzkiego. Priorytetowym powinno się więc stać doposażenie tych jednostek w sprzęt komputerowy z dostępem do Internetu.

\section{Umiejętności w zakresie wykorzystania komputerów wśród uczniów szkół ponadgimnazjalnych ${ }^{5}$}

W badaniach ankietowych Bilans Kapitału Ludzkiego 2010 udział wzięło 2125 uczniów szkół ponadgimnazjalnych z województwa łódzkiego. Kobiety stanowiły blisko $52 \%$ badanej populacji. Jedynie $2,7 \%$ przebadanej populacji stanowiły osoby uczące się w placówkach wiejskich. Badanie miało nawiązywać swą strukturą do obecnych warunków, panujących w szkolnictwie ponadgimnazjalnym w województwie łódzkim. Wśród ankietowanych znakomitą większość stanowili uczniowie liceów ogólnokształcących (59\%), kolejnymi grupami w badaniu była młodzież uczęszczająca do techników (24\%), zasadniczych szkół zawodowych (11\%) oraz liceów profilowanych (6\%).

Za punkt wyjścia analizy uznano kwestie wykorzystywania przez uczniów komputerów. Blisko 98,7\% ankietowanych miało możliwość skorzystania z komputera osobistego w domu, 93,5\% respondentów deklarowało posiadanie komputerów z dostępem do sieci Internet. Jeśli chodzi o dostęp do komputera $\mathrm{w}$ domu, najwyższy odsetek uczniów z komputerami miały licea profilowane (100\%), najniższy zaś zasadnicze szkoły zawodowe (94\%). W przypadku techników i liceów ogólnokształcących wartości wskaźnika były zbliżone i wynosiły

${ }^{5}$ Wszystkie dane użyte w podrozdziale pochodzą z baz danych badania Bilans Kapitału Ludzkiego 2010. 
odpowiednio: 99,4\% i 99,1\%. Analiza przeprowadzona wśród młodzieży pozwoliła również stwierdzić, że największa liczba uczniów posiadających komputer $\mathrm{z}$ dostępem do Internetu zidentyfikowana została w liceach profilowanych (97,4\%), najmniejszą liczbą takich uczniów charakteryzowały się zasadnicze szkoły zawodowe $(81,7 \%)$. W przypadku techników 92,3\% uczniów deklarowało możliwość skorzystania $\mathrm{z}$ Internetu $\mathrm{w}$ domu, natomiast $\mathrm{w}$ liceach ogólnokształcących było to $95,9 \%$. Pokazuje to, że najliczniejszym dostępem do komputera i Internetu charakteryzowali się uczniowie liceów profilowanych oraz liceów ogólnokształcących.

Rysunek 3. Struktura badania według typu szkoły

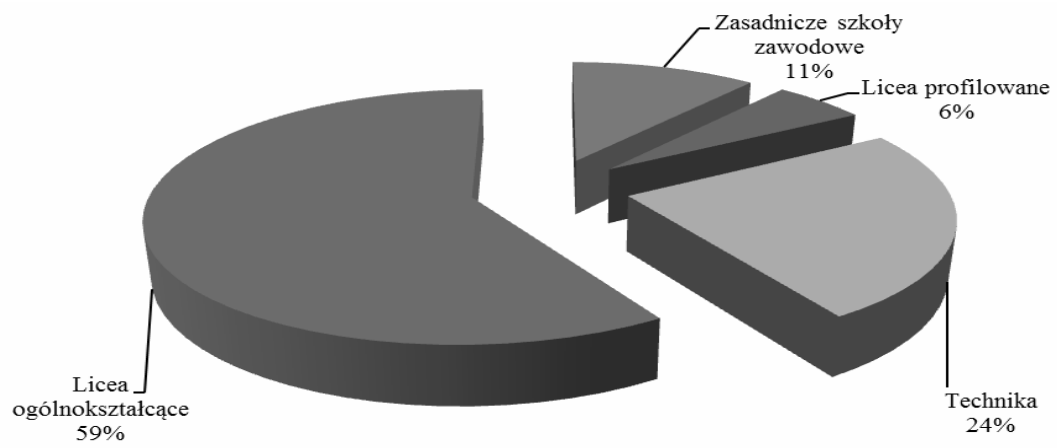

Źródło: Opracowanie własne na podstawie Bilansu Kapitału Ludzkiego 2010.

Na podstawie wstępnych analiz przeprowadzono weryfikację umiejętności posiadanych przez uczniów szkół ponadgimnazjalnych, dotyczących wykorzystania komputera i Internetu. Na pytania z tego zakresu uczniowie odpowiadali używając pięciostopniowej skali. Ogólne pytanie o umiejętności związane z komputerem i Internetem pokazało, że średnia ocen wyniosła 4,08. Najczęściej wskazywaną wartością - modą, była ocena 4 . W przypadku męskiej części populacji można mówić o wyższym stopniu umiejętności w tym zakresie, gdyż średnia ocen wyniosła 4,21, gdy u kobiet zanotowano wartość 3,97. O ile dominantą w przypadku kobiet była ocena 4, o tyle mężczyźni najczęściej wskazywali wartość 5. Weryfikacja średnich ocen umiejętności posługiwania się komputerem w poszczególnych typach szkół pozwala stwierdzić, że najwyższe kompetencje posiadają uczniowie liceów profilowanych $(4,47)$ oraz techników $(4,15)$. Podobne wartościowanie zostało stwierdzone w przypadku liceów ogólnokształcących i zasadniczych szkół zawodowych, gdzie stwierdzono odpowiednio śred- 
nie oceny na poziomie: 4,03 i 4,02. W liceach profilowanych modą było wskazanie oceny $5, \mathrm{w}$ pozostałych typach szkół ponadgimnazjalnych padały oceny równe 4. Analiza średnich wartości wskazuje, że jedynie w przypadku uczniów liceów profilowanych stwierdzono znaczącą różnicę, w odniesieniu do wartości średniej notowanej dla Polski. Różnica ta wyniosła 0,32 na korzyść uczniów ze szkół województwa łódzkiego. W przypadku pozostałych szkół różnice te nie przekraczały 0,04 punktu. Niemal we wszystkich typach szkół ponadgimnazjalnych, z wyjątkiem zasadniczych szkół zawodowych, mężczyźni deklarowali wyższe oceny umiejętności $\mathrm{w}$ zakresie wykorzystania komputera i Internetu. W przypadku techników średnie oceny wskazane przez mężczyzn są o 0,38 punktu wyższe. Różnice w przypadku liceów ogólnokształcących i liceów profilowanych były niższe i wynosiły odpowiednio: 0,28 i 0,22 punktu. W zasadniczych szkołach zawodowych wyższe kompetencje zostały wskazane przez kobiety, w omawianym typie szkół różnica ta wyniosła zaledwie 0,04 punktu.

Ważnym elementem w przyszłej karierze zawodowej jest znajomość pakietu biurowego Office, która oceniona została przez respondentów badania na poziomie 3,71 punktu. W tym zakresie wyższy poziom kwalifikacji wykazali mężczyźni, którzy średnio w badaniu ocenili swoje umiejętności na poziomie 3,85 punktu. W populacji kobiet ocena ta wyniosła 3,58. Na podstawie badania można uznać, że modą w odniesieniu do tego pytania była ocena 4, odnosi się to również do podziału populacji ze względu na płeć. Rozważania na temat umiejętności w zakresie wykorzystania pakietu Office, z uwzględnieniem rodzaju szkoły ponadgimnazjalnej, pozwala na wnioskowanie, że najwyższe kompetencje w tym zakresie posiadają uczniowie liceów profilowanych. W szkołach tych umiejętności uczniów zostały ocenione na poziomie 4,2 punktu. Niższym poziomem umiejętności wykazują się uczniowie techników, gdzie średnie oceny wyniosły 3,78 . Zbliżony poziom prezentuje młodzież uczęszczająca do liceów ogólnokształcących $(3,67)$. Najmniejszym poziomem kwalifikacji wykazali się uczniowie zasadniczych szkół zawodowych, gdzie średnia ocena wyniosła 3,52 punktu. Podobnie jak w przypadku pierwszej części pytania, modą w liceach profilowanych była ocena 5 , natomiast pozostałe typy szkół charakteryzowały się modą na poziomie 4 . W odniesieniu do średniej notowanej dla kraju należy uznać, że uczniowie liceów ogólnokształcących i techników wykazali zbliżony poziom umiejętności. W przypadku uczniów liceów profilowanych i zasadniczych szkół zawodowych, osoby kształcące się w województwie łódzkim wykazały wyższe umiejętności $\mathrm{w}$ tym zakresie, odpowiednio o: 0,61 i 0,28 . We wszystkich badanych typach szkół mężczyźni wykazują wyższe kwalifikacje w zakresie użytkowania pakietu biurowego. Największe różnice zanotowano w liceach profilowanych i liceach ogólnokształcących, gdzie wyniki ze względu na płeć respondenta różniły się odpowiednio o: 0,39 i 0,35 punktu. W przypadku 
zasadniczych szkół zawodowych i techników, różnice kwalifikacji miały ten sam poziom i wyniosły 0,17 punktu.

W zakresie umiejętności przeszukiwania Internetu oraz korzystania z poczty elektronicznej średnia ocena wyniosła 4,29 punktu. W przypadku tego rodzaju umiejętności mężczyźni wskazali niższe oceny. Żeńska część populacji wskazała ocenę 4,31 punktu, gdy średnie wskazania mężczyzn wyniosły 4,26. Analiza całej populacji oraz populacji ze względu na płeć respondenta wykazała, że modą w tym pytaniu była ocena 5. Jeśli chodzi o umiejętności uczniów poszczególnych typów szkół, najwyższymi kwalifikacjami w omawianym zakresie wykazywali się uczniowie liceów profilowanych, gdzie średnia ocena wyniosła 4,59. Młodzież uczęszczająca do liceów ogólnokształcących swoje umiejętności w zakresie przeszukiwania Internetu i korzystania z poczty elektronicznej oceniła na 4,36 . W technikach ocena ta wyniosła 4,27 . Najniższą oceną charakteryzowały się osoby kształcące się w zasadniczych szkołach zawodowych, gdzie średnia wyniosła 3,8 punktu. We wszystkich typach szkół modą była ocena 5 . Podobnie jak w przypadku znajomości pakietu Office umiejętności uczniów liceów ogólnokształcących i techników były zbliżone do wartości średnich notowanych w kraju. Wyższymi kwalifikacjami wykazywali się uczniowie liceów profilowanych (średnia ocena wyższa o 0,25 od średniej krajowej), natomiast niższą uczniowie zasadniczych szkół zawodowych (średnia ocena niższa o 0,14 od średniej krajowej). Analiza różnic ocen umiejętności w podziale na płeć, prowadzi do wniosku, że w zasadniczych szkołach zawodowych i technikach kobiety charakteryzowały się wyższymi kwalifikacjami, w zakresie przeszukiwania stron internetowych oraz obsługi poczty i programów pocztowych. W przypadku pozostałych szkół ponadgimnazjalnych poddanych badaniu analiza wykazała, że mężczyźni posiadają nieznacznie wyższe kwalifikacje w tym zakresie.

Obok określenia podstawowych umiejętności korzystania z komputera i Internetu, respondenci badania zostali zapytani o znajomość oprogramowania, które pozwala na pisanie programów i stron internetowych. Można uznać, że w tej materii kwalifikacje uczniów szkół ponadgimnazjalnych wykazują najniższe wartości punktowe. Średnia ocena uzyskana w badaniu wyniosła 2,37 punktu. W zakresie znajomości specjalistycznego oprogramowania, podobnie jak we wcześniejszych wypadkach, wyższe kwalifikacje wskazali mężczyźni. Różnica punktowa wyniosła nieco ponad 0,4, mężczyźni bowiem średnio ocenili swoje umiejętności na 2,59 punktu, kobiety natomiast na 2,18 punktu. Modą dla pytania była ocena 2, uwzględnienie płci respondentów pozwala stwierdzić, że kobiety najczęściej wskazywały ocenę 2 , mężczyźni natomiast 3 . Porównując wartości wskaźników w województwie łódzkim ze średnią dla Polski, należy stwierdzić, że we wszystkich typach szkół, z wyjątkiem liceów profilowanych, był on bardzo zbliżony. W przypadku liceów profilowanych w województwie 
łódzkim, uczniowie wskazywali oceny wyższe średnio o 0,13 punktu. Weryfikacja umiejętności w poszczególnych typach szkół, mimo że nie napawa optymizmem, pokazuje, że w liceach profilowanych poziom umiejętności wśród uczniów jest najwyższy i wynosi 2,66 punktu. Kwalifikacje swoje na poziomie 2,55 punktu ocenili uczniowie zasadniczych szkół zawodowych, co było drugim wynikiem wśród szkół ponadgimnazjalnych. Nieco niższy poziom kwalifikacji wykazała młodzież uczęszczająca do techników, gdzie ocena średnia wyniosła 2,45. Najniższe kompetencje w sferze znajomości oprogramowania programistycznego wykazali uczniowie liceów ogólnokształcących, których wynik wyniósł 2,28 punktu. Prowadzone analizy wykazały, że modą w przypadku zasadniczych szkół zawodowych i liceów ogólnokształcących była ocena 2, w przypadku liceów profilowanych i techników wartość mody wyniosła 3 . W zakresie omawianych umiejętności widoczna jest dominacja szkół technicznych i zawodowych nad szkolnictwem ogólnokształcącym. We wszystkich typach szkół ponadgimnazjalnych badanie wykazało wyższy poziom umiejętności $\mathrm{w}$ grupie mężczyzn. Najwyższe różnice w średnich ocenach zidentyfikowano w liceach profilowanych. Różnice te wyniosły 0,55 punktu. W liceach ogólnokształcących mężczyźni mieli wyższe kwalifikacje średnio o 0,41 punktu. W technikach różnice te wyniosły 0,32, a w zasadniczych szkołach zawodowych jedynie 0,25.

Porównanie województwa łódzkiego oraz Polski nasuwa wniosek, że umiejętności podstawowe zgłaszane przez uczniów szkół ponadgimnazjalnych mają porównywalny poziom. Wyjątek stanowią uczniowie liceów profilowanych, którzy w zakresie tych umiejętności wskazywali wyższe oceny. Ważnym elementem, budującym pozytywny wizerunek kapitału ludzkiego w regionie, jest umiejętność wykorzystywania oprogramowania programistycznego. W tym zakresie największe kwalifikacje wykazywali ponownie uczniowie liceów profilowanych, których oceny były wyższe od średniej krajowej. Rozwijający się więc kapitał ludzki, pozwolić może na rozwój branży IT w regionie łódzkim.

\section{Zaplecze infrastrukturalne a umiejętności uczniów w zakresie wykorzystania komputera i Internetu}

Przeprowadzone analizy, dotyczące dostępności komputerów z siecią Internet oraz kwalifikacji uczniów szkół ponadgimnazjalnych, w zakresie wykorzystania tego rodzaju sprzętu, pozwalają na zestawienie wyników i ocenę wpływu dostępności, na poziom umiejętności deklarowany przez młodzież. W tym celu przeprowadzono rangowanie, czyli porządkowanie zmiennych ze względu na wartość wskaźnika użytego w badaniu. W przypadku oceny liczby komputerów $\mathrm{z}$ dostępem do sieci Internet $\mathrm{w}$ szkołach ponadgimnazjalnych, mamy do zweryfikowania dwa wskaźniki. Wskaźnik prezentujący odsetek szkół posiadających 
w wyposażeniu komputery z dostępem do Internetu należy uznać za stymulantę w zakresie omawianego zjawiska. Oznacza to, że wyższe wartości wskaźnika w sposób pozytywny wpływają na dostępność komputerów w poszczególnych typach szkół. Jeżeli chodzi zaś o wskaźnik liczby uczniów przypadających na jeden komputer podłączony do sieci Internet, zmienną należy uznać za destymulantę. Wynika to z faktu, że mniejsza liczba uczniów przypadająca na stanowisko pracy świadczy o lepszej dostępności sprzętu komputerowego w szkole. $\mathrm{W}$ odniesieniu do ocen dotyczących umiejętności w zakresie wykorzystania komputerów i Internetu, wszystkie elementy należy uznać za stymulanty. W dalszych analizach wykorzystane zostaną trzy wskaźniki, opisujące umiejętności uczniów szkół ponadgimnazjalnych w zakresie: znajomości pakietu Office, umiejętności przeszukiwania Internetu i korzystania z poczty elektronicznej oraz znajomości oprogramowania, które pozwala na pisanie programów i stron internetowych.

Tabela 4. Wskaźniki wykorzystane do ustalenia lokaty poszczególnych typów szkół ponadgimnazjalnych

\begin{tabular}{|c|l|}
\hline X1 & Odsetek szkół posiadających w wyposażeniu komputery z dostępem do Internetu \\
\hline X2 & Liczba uczniów przypadających na jeden komputer podłączony do sieci Internet \\
\hline X3 & Znajomość pakietu Office \\
\hline X4 & Umiejętność przeszukiwania Internetu oraz korzystania z poczty elektronicznej \\
\hline X5 & Znajomość oprogramowania, które pozwala na pisanie programów i stron internetowych \\
\hline
\end{tabular}

Źródło: Opracowanie własne.

Stosując te założenia, dokonano oceny lokat poszczególnych typów szkół, pod względem dostępności sprzętu komputerowego. Zestawiając ze sobą rangi, oszacowane dla wskaźnika odsetka szkół z komputerami z dostępem do Internetu oraz lokatę uzyskaną po zestawieniu ze sobą danych, odnoszących się do umiejętności młodzieży w poszczególnych typach szkół należy uznać, że rangi w poszczególnych zestawieniach nie w pełni pokrywają się ze sobą. Nasuwają się wnioski, że dostępność wyposażenia komputerowego w technikach i zasadniczych szkołach zawodowych przekłada się na poziom umiejętności, jakie w badaniu zgłoszone zostały przez uczniów tych szkół. W przypadku liceów ogólnokształcących, szkoły posiadają dobre wyposażenie w sprzęt komputerowy, co jednak nie przekłada się na umiejętności zgłaszane przez uczniów. W przypadku liceów profilowanych widoczne są odwrotne tendencje, gdyż słabsze wyposażenie szkół skutkuje wysokimi umiejętnościami zgłaszanymi przez uczniów. Pomimo trzeciej lokaty w rankingu pod względem odsetka szkół z komputerami z przyłączem do Internetu, można wnioskować, że profil kształ- 
cenia w liceach profilowanych, zakłada rozwój umiejętności związanych z wykorzystywaniem komputera i Internetu. Wnioski te pozwalają również na stwierdzenie, że zgodnie z teorią kapitału ludzkiego kwalifikacje uczniów są podnoszone w procesie kształcenia i prowadzą do rozwoju poszczególnych osób.

Tabela 5. Rangi dla danych dotyczących dostępności komputerów w szkołach

\begin{tabular}{|l|c|c|c|c|}
\hline \multicolumn{1}{|c|}{ Typ szkoły } & Wartość X1 & $\begin{array}{c}\text { Ranga dla } \\
\text { X1 }\end{array}$ & Wartość X2 & $\begin{array}{c}\text { Ranga dla } \\
\text { X2 }\end{array}$ \\
\hline Licea ogólnokształcące & 83 & 1 & 9,7 & 3 \\
\hline Licea profilowane & 54,5 & 3 & 6,1 & 1 \\
\hline Technika & 80,6 & 2 & 6,3 & 2 \\
\hline Zasadnicze szkoły zawodowe & 29,4 & 4 & 16,8 & 4 \\
\hline
\end{tabular}

Źródło: Opracowanie własne na podstawie danych Banku Danych Lokalnych Głównego Urzędu Statystycznego.

Analiza rankingu, w zakresie dostępności komputerów z Internetem w szkołach ponadgimnazjalnych, ze względu na liczbę uczniów przypadających na jeden komputer, wykazuje pełną korelację z rankingiem umiejętności zgłaszanych przez uczniów we wszystkich typach szkół. Pokazuje to, że mimo różnic w odsetku szkół ze sprzętem komputerowym z dostępem do Internetu, obłożenie poszczególnych komputerów pozwala na osiaganie przez uczniów dostatecznych umiejętności, które znajdują potwierdzenie w badaniach ankietowych.

Tabela 6. Lokaty poszczególnych typów szkół ze względu na zgłaszane przez uczniów umiejętności

\begin{tabular}{|l|c|c|c|c|c|c|c|c|}
\hline \multicolumn{1}{|c|}{ Typ szkoły } & $\begin{array}{c}\text { Wartość } \\
\text { X3 }\end{array}$ & $\begin{array}{c}\text { Ranga } \\
\text { dla X3 }\end{array}$ & $\begin{array}{c}\text { Wartość } \\
\text { X4 }\end{array}$ & $\begin{array}{c}\text { Ranga } \\
\text { dla X4 }\end{array}$ & $\begin{array}{c}\text { Wartośćc } \\
\text { X5 }\end{array}$ & $\begin{array}{c}\text { Ranga } \\
\text { dla X5 }\end{array}$ & $\begin{array}{c}\text { Suma } \\
\text { rang }\end{array}$ & Lokata \\
\hline Licea ogólnokształcące & 3,67 & 3 & 4,36 & 2 & 2,28 & 4 & 9 & 3 \\
\hline Licea profilowane & 4,20 & 1 & 4,59 & 1 & 2,66 & 1 & 3 & 1 \\
\hline Technika & 3,78 & 2 & 4,27 & 3 & 2,45 & 3 & 8 & 2 \\
\hline $\begin{array}{l}\text { Zasadnicze szkoły } \\
\text { zawodowe }\end{array}$ & 3,52 & 4 & 3,80 & 4 & 2,55 & 2 & 10 & 4 \\
\hline
\end{tabular}

Źródło: Opracowanie własne na podstawie Bilansu Kapitału Ludzkiego 2010. 
Analiza przeprowadzona na potrzeby badania wykazuje, że jedynie w przypadku odsetka szkół z komputerami w liceach ogólnokształcących i liceach profillowanych, można uznać potwierdzenie hipotezy badawczej. Zgodnie z tym należy stwierdzić, że w przypadku tych typów szkół w województwie łódzkim, dostępność komputerów nie jest determinantą generującą umiejętności w zakresie: przeszukiwania Internetu i korzystania z poczty elektronicznej, wykorzystania pakietu biurowego Office oraz znajomości specjalistycznych programów.

\section{Podsumowanie}

Badania przeprowadzone w zakresie wybranych determinant rozwoju społeczeństwa informacyjnego, generowanych przez szkoły i system oświaty wskazują, że województwo łódzkie prezentuje się pozytywnie na tle średniej krajowej, jednak należy wciąż dążyć do upowszechniania i rozwijania umiejętności wykorzystywania komputerów oraz sieci Internet przez uczniów szkół ponadgimnazjalnych.

Wskaźniki wykorzystane do oceny dostępności komputerów z dostępem do Internetu pozwalają patrzeć z nadzieją na coraz lepszy rozwój kapitału ludzkiego w regionie. Podejście takie pozwoli również na wykształcenie pozytywnych zachowań $\mathrm{w}$ procesie tworzenia społeczeństwa informacyjnego. Elementem pozwalającym to osiagnąć, może stać się również wyrównywanie poziomu dostępności w poszczególnych typach szkół ponadgimnazjalnych, co w perspektywie wpłynie pozytywnie na ogół zjawisk związanych z rozwojem kapitału ludzkiego w regionie. Podejście takie wynikać może chociażby z faktu, że w większości placówek szkolnych $\mathrm{w}$ regionie łódzkim, poziom umiejętności był pochodną dostępności sprzętu komputerowego w szkołach. Wykorzystanie tej zależności pomoże w rozwoju kadry w regionie, poprzez kształcenie ludności zarówno na poziomie zawodowym i technicznym, jak również na poziomie wyższym, który jest pochodną kształcenia w liceach ogólnokształcących. Widoczne staje się to w szczególności, w przypadku wskaźnika znajomości oprogramowania specjalistycznego, którego poziom w liceach ogólnokształcących jest najniższy, co jest również pochodną programów realizowanych w ramach tych jednostek.

Rozwój dostępności komputerów powinien pozwolić na lepsze dostosowanie młodzieży do warunków, w których będą funkcjonować, czyli do przyszłej pracy zawodowej oraz funkcjonowania w nowym modelu społeczeństwa, opartego o osiagnięcia techniki. Rozwój kapitału ludzkiego w tym zakresie pozwoli na podniesienie konkurencyjności regionu oraz jego rozwój. Niezależnie od tego powinno się również dążyć do tego, aby oddziały szkolne oraz zajęcia z komputerami odbywały się w mniej licznych grupach zajęciowych, co pozwala na lepszą efektywność nauczania oraz lepsze przyswajanie wiedzy przez młodzież. 
Kapitał ludzki w regionie łódzkim. Społeczeństwo, edukacja, przestrzeń 73

\section{Bibliografia}

Bank Danych Lokalnych Głównego Urzędu Statystycznego.

Bilans Kapitatu Ludzkiego w Polsce. Raport podsumowujacy pierwszq edycje badań realizowana w 2010 roku, Polska Agencja Rozwoju Przedsiębiorczości, Warszawa 2011.

Haddah W.D., Draxler A., The Dynamics of Technologies for Education, 2003, http://www.ictinedtoolkit.org/usere/library/tech_for_ed_chapters/01.pdf.

Kolodziejczyk I., ICT for Education: The Way Ahead, but How?, Contemporary PNG Studies, Vol. 11, Nov 2009.

Sanchez J., Salinas A., Harris J., Education with ICT in South Korea and Chile, International Journal of Educational Development 31 (2011). 